\title{
Numerical Modeling of Liquid Feeding in the Liquid-Fed Ceramic Melter
}

R. L. Hjelm

T. E. Donovan

October 1979

Prepared for the U.S. Department of Energy under Contract EY-76-C-06-1830

Pacific Northwest Laboratory

Operated for the U.S. Department of Energy by Battelle Memorial Institute 


\title{
NOTICE
}

This report was prepared as an account of work sponsored by the United States Government. Neither the United States nor the Depariment of Energy, nor any of their employees, nor any of their contractors, subcontraciors, or their employees, makes any warranty, express or implied, or assumes any lega! liability or responsibility for the accuracy, completeness or usefulness of any information, apparatus, product or process discloseo, or represents that its use would not infringe privately owned rigints.

The views, opinions and conclusions contained in this report are those of the contractor and do not necessarily represent those of the United States Government or the United States Department of Energy.

\author{
PACIFIC NORTHWEST LABORATORY \\ uperaled by \\ BA.TTELLE \\ for the \\ UNITED STATES DEPARTIAENT OF ENERGY \\ Under Contract EY-76-C-05-1830
}

\begin{tabular}{|c|c|}
\hline \multicolumn{2}{|c|}{$\begin{array}{l}\text { Printed in the United States of America } \\
\text { Available from } \\
\text { National Zechnical Information Service } \\
\text { United States Departmen: of Commerce } \\
\text { 5265 Futl Royal Road } \\
\text { Springfield, Virginia } 22151\end{array}$} \\
\hline e: Printed Copy & Z Microticha $\$ 3.00$ \\
\hline •Pages & $\begin{array}{c}\text { NTIS } \\
\text { Selling Price }\end{array}$ \\
\hline $001-025$ & 54.00 \\
\hline 025.050 & $\$ 4.50$ \\
\hline $031-675$ & $\$ 5.25$ \\
\hline $075-100$ & 36.00 \\
\hline $101-125$ & 56.50 \\
\hline $126-150$ & 57.25 \\
\hline $151-175$ & $\$ 8 . \infty 0$ \\
\hline $176-200$ & $\$ 9.00$ \\
\hline $201-225$ & $\$ 9.25$ \\
\hline $226-250$ & $\$ 9.50$ \\
\hline $251-275$ & 510.75 \\
\hline $26 \cdot 700$ & 571.07 \\
\hline
\end{tabular}


PNL -3137

UC -70

33679000536047

NUMERICAL MODELING OF LIQUID FEEDING

IN THE LIQUID-FED CERAMIC MELTER

R. L. Hjelm

T. E. Donovan

October 1979

Prepared for the

U.S. Department of Energy

under Contract EY-76-C-06-1830

Pacific Northwest Laboratory

Richland, Washington 99352 


\section{SUMMARY}

A modeling scheme developed by the Pacific Northwest Laboratory numerically simulates the behavior of the Liquid-Fed Ceramic Melter (LFCM) during liquid feeding. The computer code VECTRA (Vorticity Energy Code for TRansport Analysis) was used to simulate the LFCM in the idling and liquid feeding modes. Results for each simulation include molten glass temperature profiles and isotherm contour plots, stream function contour plots, heat generation rate contour plots, refractory isotherms, and heat balances.

The results indicated that the model showed no major deviations from real LFCM behavior and that high throughput should be attainable. They also indicated that reboil was a possibility as a steady liquid feeding state was approached, very steep temperature gradients exist in the Monofrax $\mathrm{K}-3$, and that phase separation could occur in the bottom corners during liquid feeding and over the entire floor while idling. 


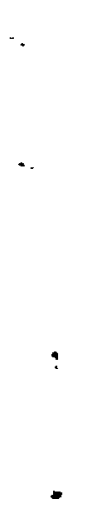




\section{CONTENTS}

SUMMARY
FIGURES


$\ddots$

- 


\section{FIGURES}

1 Schematic of Model Used to Simulate LFCM $\quad$ • $\quad$ • $\quad$ • $\quad$ • $\quad$ - 5

2 Liquid-Fed Ceramic Melter Central Portion

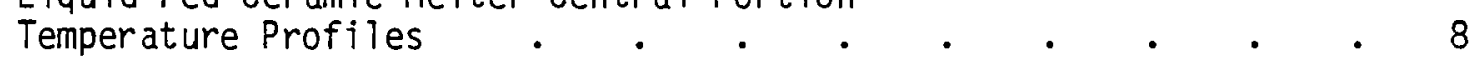

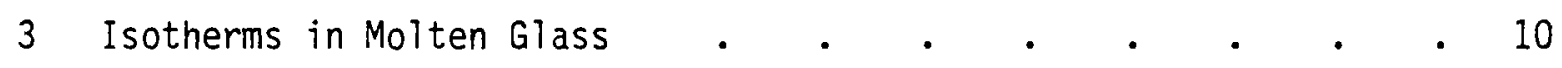

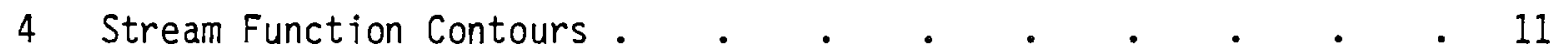

5 Normalized Heat Generation Rate Contours . . . . . 13

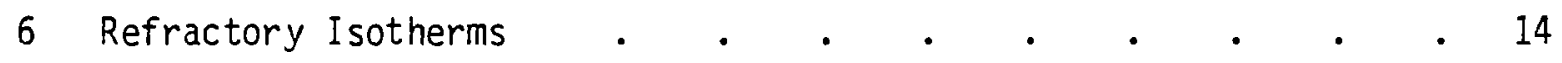



NUMERICAL MODELING OF LIQUID FEEDING

OF THE LIQUID-FED CERAMIC MELTER

\section{INTRODUCTION}

This report describes a modeling scheme developed at the Pacific Northwest Laboratory (PNL) to numerically simulate the behavior of the Liquid-Fed Ceramic Melter (LFCM) while directly feeding simulated liquid high level wastes. The LFCM ${ }^{(1)}$ is an integral part of the High Level Waste Immobilization Process currently under development at PNL for the U.S. Department of Energy (DOE).

The extreme environment in the melter substantially limits observation and direct measurement efforts to obtain information about the molten glass behavior. In addition, physical changes in the LFCM are cost7y, thus inhibiting direct experimentation with the actual melter. For these reasons, numerical modeling can be a valuable adjunct in documenting and explaining the physical processes of the molten glass. Further, it can provide operating and design information to support the melter development work.

The PNL-developed computer code VECTRA was used in this study to simulate the LFCM in two operating modes. VECTRA is a two-dimensional code that can solve the vorticity, stream function, energy, and electric field equations in a wide variety of geometries. (2) The code had been used previously to simulate molten glass flows. (3) Numerical results generated by the code have been compared with good agreement to measurements taken on the LFCM physica? mode1. (4) For these reasons, VECTRA was used to simulate the LFCM in both the idling and liquid feed modes. The objective was to observe and understand the similarities and differences in LFCM behavior in both cases.

This report briefly summarizes how the LFCM operates, to provide the background necessary to the feeding and idling model descriptions. Results of the idling and feeding simulations are then documented. The final sections discuss the simulation results and conclusions. 
$\because$

: 


\section{FEEDING AND IDLING MODELS}

As background, LFCM operation is briefly described first in this section. The models used to simulate the LFCM idling and liquid feeding modes are then presented.

\section{LIQUID-FED CERAMIC MELTER OPERATION}

In the High Level Waste Immobilization process, the waste is mixed with glass additives and melted to produce a stable glass product suitable for long-term storage in metal canisters. The LFCM heats the molten glass by passing an electric current through it. The current is supplied by electrodes placed on opposing melter walls. The LFCM has two independent sets of electrodes: a lower set along the melter floor and an upper set 4 in. above the lower set. Because the two electrode sets are independent, the ratio of the power input through the upper set to the power input through the lower set (power skew) can be varied. At the LFCM operating temperature, the glass has the properties of an electrically conductive fluid. The heat loss through the melter sides cools the glass adjacent to the walls, causing it to become denser and sink to the bottom. This sinking motion establishes a circulation pattern in the glass melter. Thus, the hydrodynamic behavior in the melter is coupled to its electric and thermodynamic characteristics.

The behavior of the LFCM is significantly different during liquid feeding than while idling (no feeding). $(5,6)$ While idling, the glass melt is entirely molten, with the top of the glass transferring heat by radiation up across an air gap to the melter lid. While feeding, cold liquid is poured directly onto the hot glass melt. During a steady feeding state, a crust (cold cap) exists on top of the glass melt. Above this cold cap is a layer of liquid at the liquid boiling temperature $\left(\sim 150^{\circ} \mathrm{C}\right)$. Thus, heat transfer by radiation at the glass batch top is negligible during liquid feeding. In addition, because of throughput during feeding, the required power input is much larger than that required to maintain the glass at operating temperature $\left(1200^{\circ} \mathrm{C}\right)$ during idling. 


\section{FEEDING AND IDLING MODELS}

Because the top of the glass melt changes with operating mode, different models are required to simulate the LFCM during idling and during liquid feeding. A schematic of the system simulated by VECTRA for the liquid feeding case is shown in Figure $1 \mathrm{a}$; that for the idling case is shown in Figure $1 \mathrm{~b}$. Only half of each cross section is shown, because the LFCM is symmetric in that plane. However, the entire cross section was simulated by VECTRA.

The refractory walls surrounding the glass melt, as well as the electrodes and the boundary conditions, are the same in both the idling and liquid feeding models. Differences exist at the top of the glass melt. For the idling case, a radiation boundary at the top of the glass melt transfers heat by radiation from the molten glass, across the vapor gap, to the Kaowool insulation lid. The Kaowool insulation lid in turn transfers heat by radiation and conduction to the ambient atmosphere above it.

For the liquid feeding case, a uniform batch crust 2 in. thick is established at the top of the glass melt. The thermal conductivity of this crust is assumed to be $0.5 \mathrm{Btu} / \mathrm{hr}-\mathrm{ft}-{ }^{\circ} \mathrm{F}$, based on the measured value for glass at $700^{\circ} \mathrm{C}$. The bottom of this crust acts as a no-slip boundary for the molten glass below. There is little data available on the actual structure or properties of the batch crust in the LFCM. The above assumptions are made based on the available information, but it is nearly impossible to validate these idealizations required to perform the analysis. The feed into the glass melt is assumed to occur at the bottom of the batch crust. The outflow is assumed to occur at the center of the melter floor. In the actual LFCM, the outflow takes place on a wall outside the plane simulated by VECTRA. To conserve mass in the simulation, it is necessary to place the outflow along the melter floor. Above the batch crust is a $0.5-i n$. thick liquid layer held at a constant, uniform temperature of $150^{\circ} \mathrm{C}$. This temperature is assumed to be the boiling temperature of the liquid feed. To account for endothermic reactions that take place in the batch crust, a heat sink totalling $-2 \mathrm{~kW}$ is applied to the crust. 


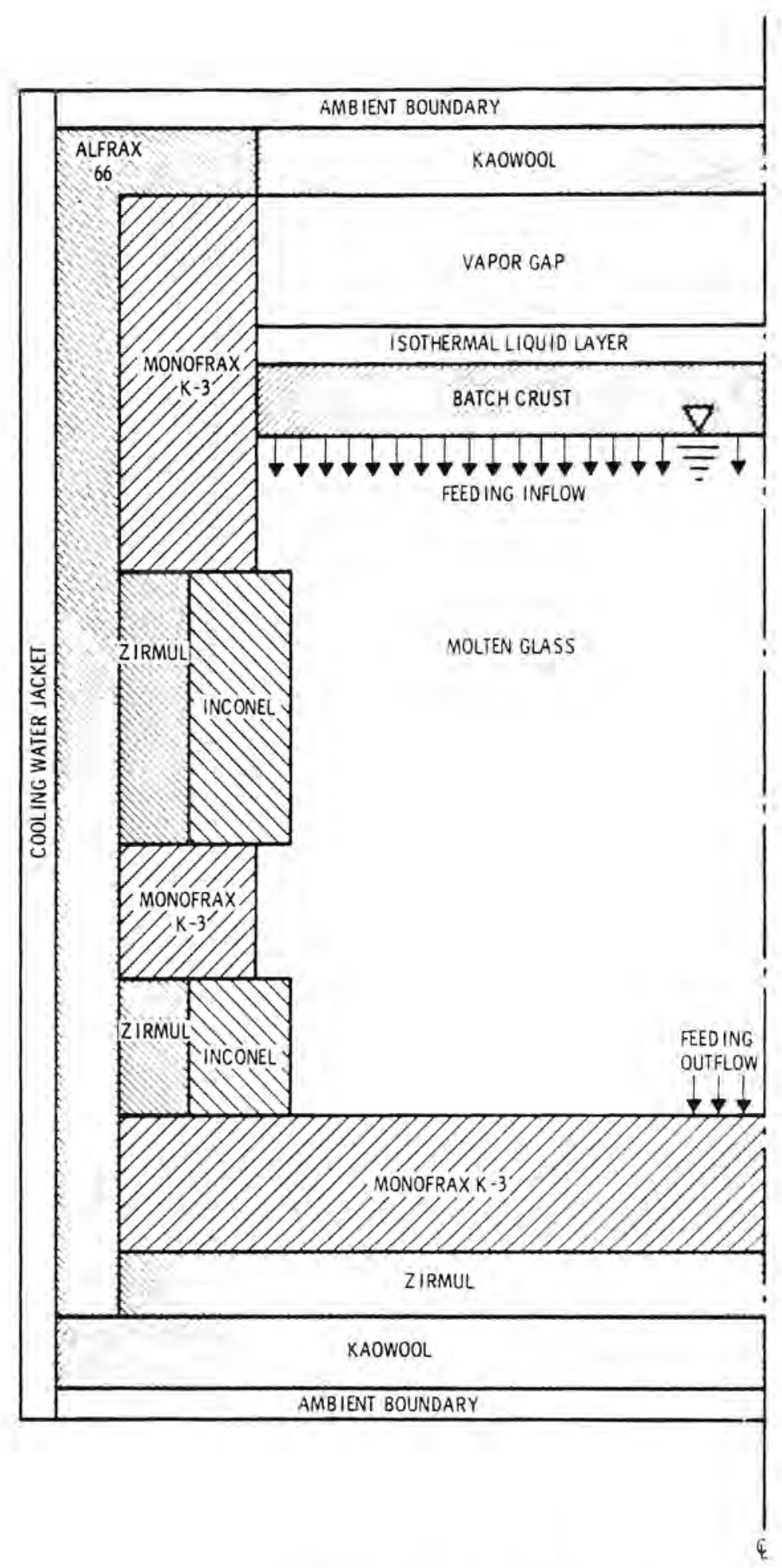

a. Liquid Feeding Mode

FIGURE 1. Schematic of Model Used to Simulate LFCM 


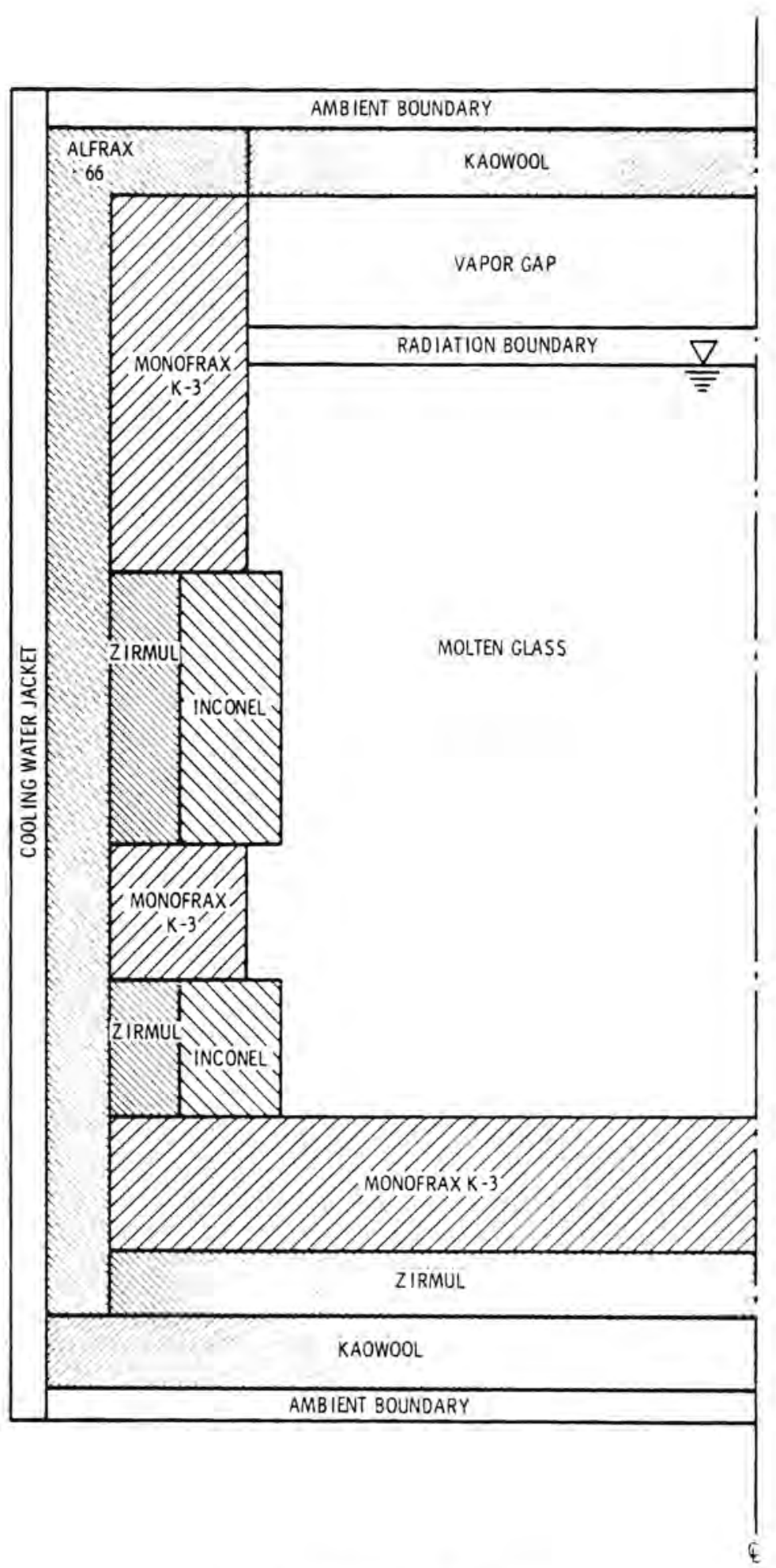

b. Idling Mode

FIGURE 1. (contd) 


\section{$\underline{\text { RESULTS }}$}

The idling and liquid feeding simulations were executed by VECTRA until a steady energy state was reached, i.e., until the heat transfer out of the system equaled the power input. (As described in Reference 3, the flow field never achieves a steady state.) The controlling parameter for each case was the electrode temperature. An electrode temperature of $1050^{\circ} \mathrm{C}$ was the goal because this is the temperature control point in actual operation. For idling, the result was $1049^{\circ} \mathrm{C}$; for liquid feeding, the electrode temperature was $1062{ }^{\circ} \mathrm{C}$. The boundary temperatures for both cases were an ambient temperature of $27^{\circ} \mathrm{C}$ and a c0oling jacket temperature of $38^{\circ} \mathrm{C}$.

\section{POWER REQUIREMENTS}

The idling simulation of the $L F C M$ required $9.5 \mathrm{~kW} / \mathrm{ft}$, or $27 \mathrm{~kW}$ total, to maintain the electrode temperature at $1050^{\circ} \mathrm{C}$. Because of throughput and the isothermal boundary that accounts for heat of vaporization at the cold cap, the liquid feeding case required much more power to maintain an electrode temperature of $1050^{\circ} \mathrm{C}--29 \mathrm{~kW} / \mathrm{ft}$, or $82 \mathrm{~kW}$ overall. This latter value compares very well to the actual prototype power requirements of $90 \mathrm{~kW}$ for a similar feed rate. The power required for idling, $27 \mathrm{~kW}$, is significantly less than that required in the actual LFCM. Two reasons for this difference are possible. First, the model assumes that there is no heat transfer in the direction perpendicular to the plane modeled. This is a poor but necessary assumption in two-dimensional modeling. Second, there is less insulation on the lid of the actual LFCM than was used in the model. Thus, the simulation assumed a better insulated melter than the actual LFCM. Both cases were run with $75 \%$ of the power input through the upper electrodes.

\section{TEMPERATURES IN THE MELTING CAVITY}

Figure 2 illustrates the temperature profile of the central portion of the melter from the floor up to the Kaowool lid. In the liquid feeding case (Figure 2a), the molten glass temperature is fairly uniform from the floor up 


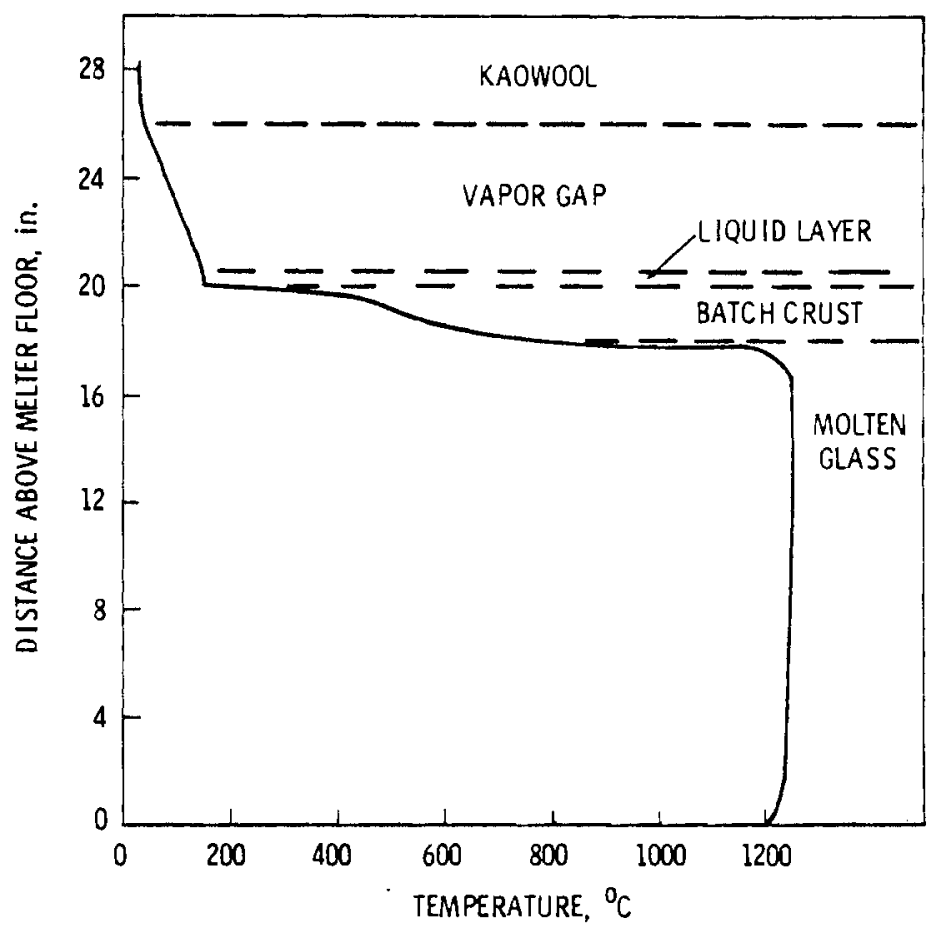

a. Liquid Feeding Mode

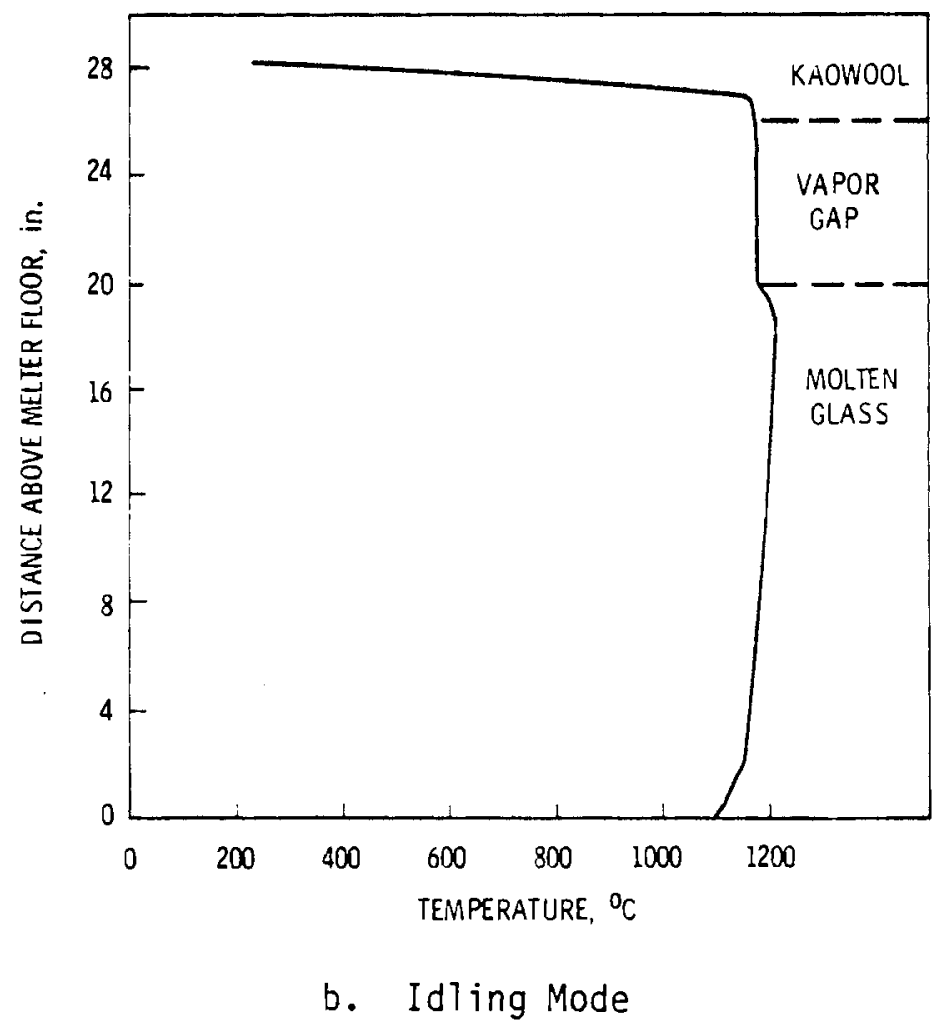

FIGURE 2. Liquid-Fed Ceramic Melter Central Portion Temperature Profiles 
to near the crust, where there is a very steep temperature gradient between the bulk glass and the crust. The interface temperature is computed to be $760^{\circ} \mathrm{C}$, which is very close to the actual temperature at which glass begins to melt. This implies that the assumptions used to model the top of the molten glass during feeding work fairly well. The temperature continues to drop in the batch crust until the $150^{\circ} \mathrm{C}$ liquid layer is reached. Above the liquid layer the temperatures decline gradually to the ambient temperature.

The temperature profile while idling (Figure 2b) is significantly different from the liquid feeding case. The floor temperature is lower and a larger temperature gradient is present in the bottom part of the melter while idling. The fluid temperature is generally lower than while feeding. While idling, there is no crust above the glass melt, so the temperature peaks $18 \mathrm{in}$. above the floor and then cools slightly at the top of the melt. This surface then transfers heat by radiation to the lid. Notice that there is almost no temperature drop across the vapor gap. The temperature change between ambient and the glass melt top occurs almost entirely in the Kaowool lid insulation.

Figure 3 illustrates isotherms in the molten glass for the idling and feeding cases. Figure $3 a$, the feeding case, shows that the glass temperature is very uniform except in the bottom corners, where there are definite cold spots. The temperature drop from the floor center to the corners is about $80^{\circ} \mathrm{C}$. In the idling case shown in Figure $3 \mathrm{~b}$, the isotherms illustrate a temperature gradient from the top of the melt to the bottom, but indicate that the glass temperature is nearly uniform along a traverse between electrodes. Thus, in the idling case, the entire floor is colder, instead of just the corners as in the feeding case.

\section{FLOW FIELDS}

Figure 4 presents stream function contour plots for the feeding and idling cases. The same values of the stream function are plotted for each case. The differences between Figure $4 \mathrm{a}$ and $4 \mathrm{~b}$ indicate that the glass velocities in the feeding case are two to three times higher than in the idling 


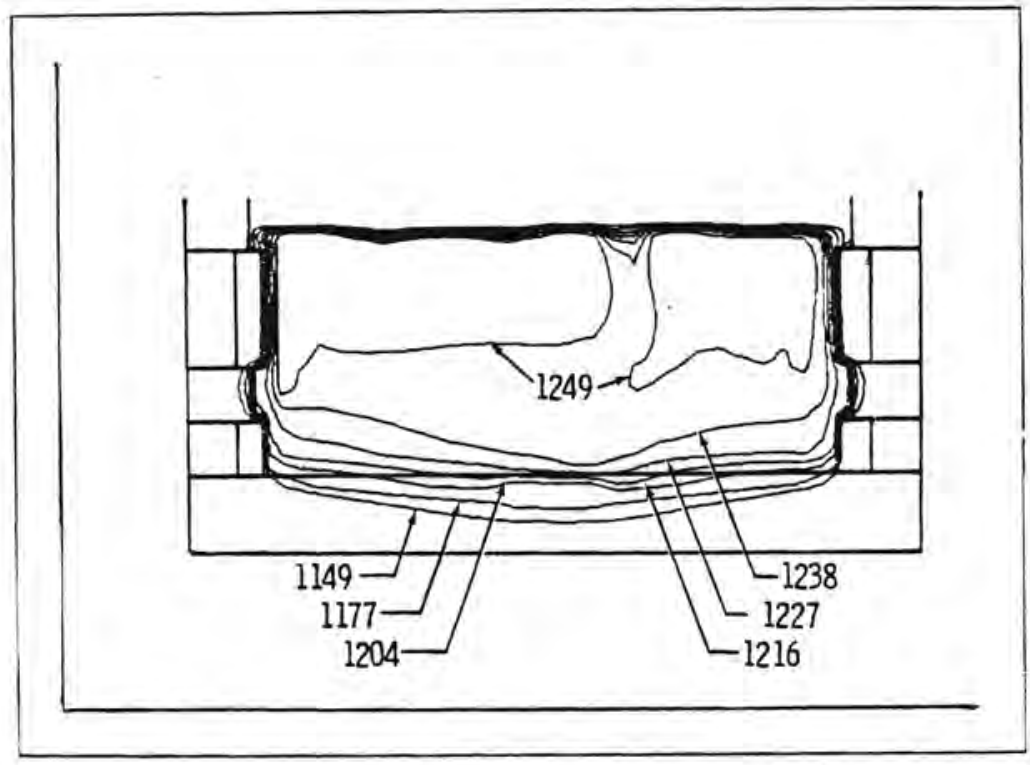

a. During Liquid Feeding

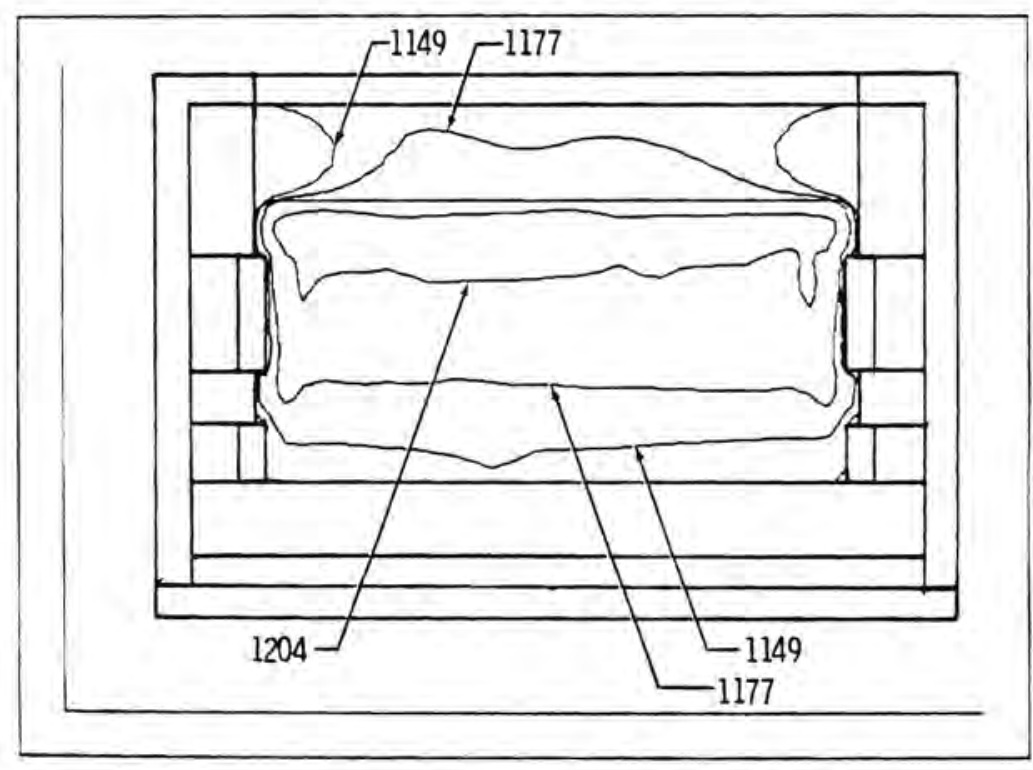

b. While Idling

FIGURE 3. Isotherms in Molten Glass (Contour Values in ${ }^{\circ} \mathrm{C}$ ) 


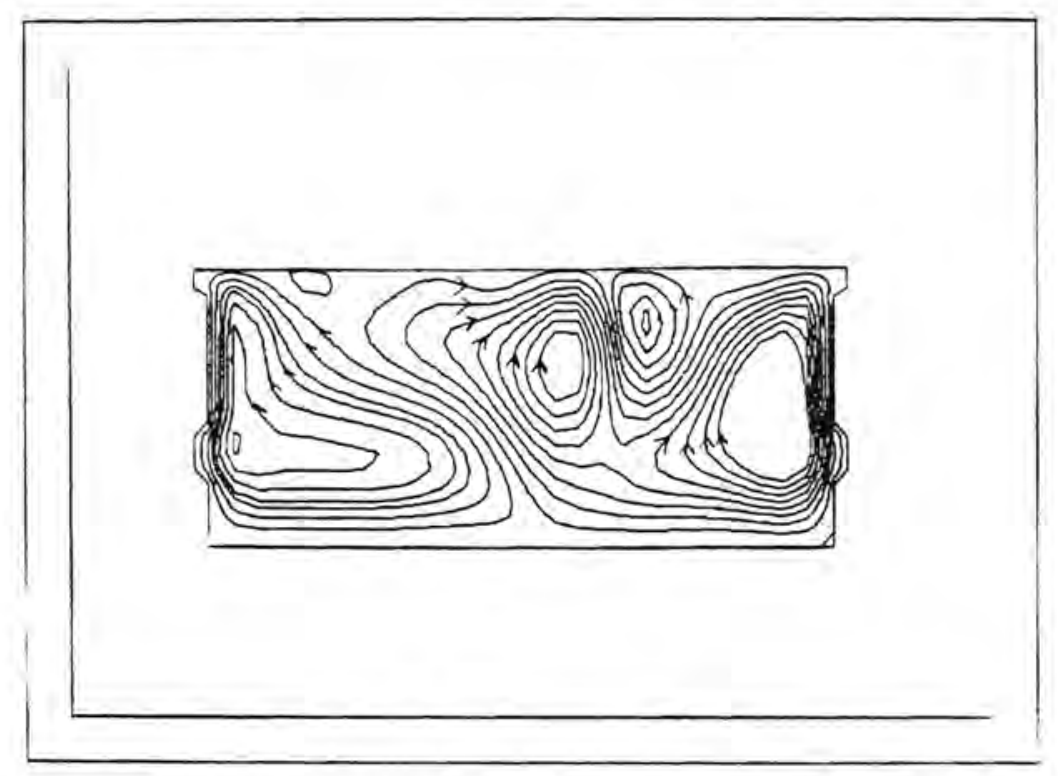

a. During Liquid Feeding

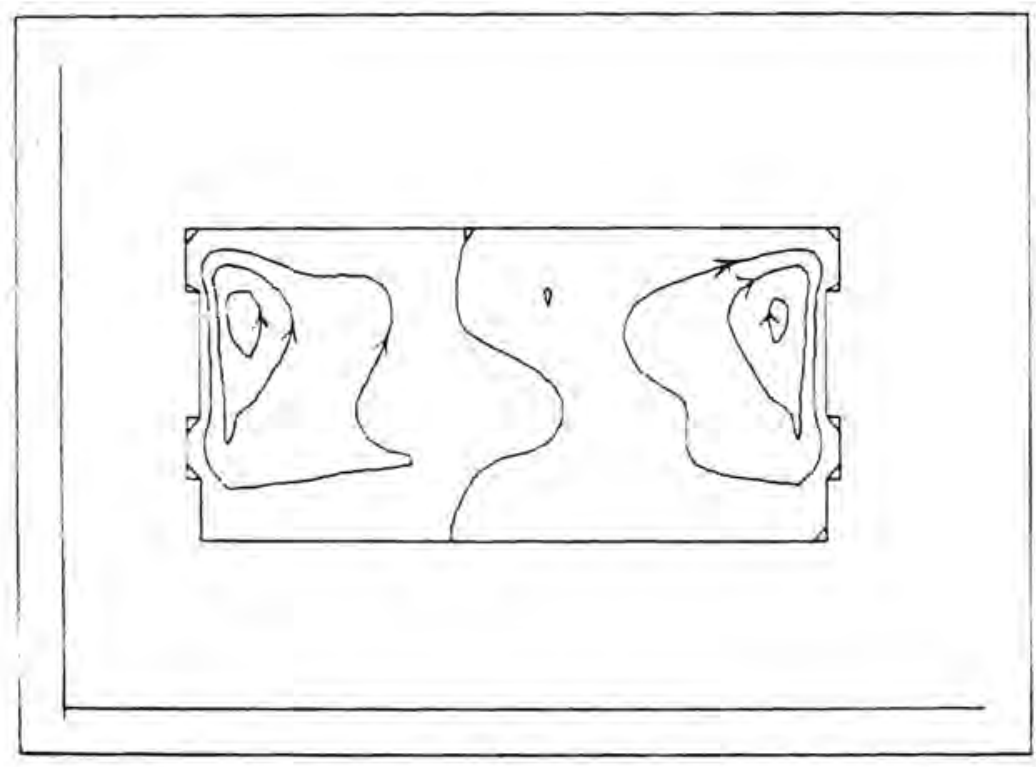

b. While Idling

FIGURE 4. Stream Function Contours 
case.- The steep temperature gradient at the glass melt top in the feeding case cools the glass there more, thus causing it to fall into the warmer glass below with greater velocity. Higher velocities for the feeding case lead to a better-mixed, more uniform temperature fluid. This helps explain why the glass is warmer in the bottom half of the melter during feeding.

\section{HEAT GENERATION RATES}

Because the power skew is the same for both idling and feeding cases, differences in only the temperature field will lead to differences in the heat generation field. Figure 5 illustrates the heat generation fields for liquid feeding and idling cases. The contours plotted are the local value of heat generation rate divided by the average heat generation rate. A comparison shows that heat is generated more uniformly in the feeding case because of more uniform glass temperatures. This is especially noticeable in the bottom center region of the melter. At the melter top, the feeding case heat generation rate drops, due to the steep temperature gradient there.

\section{HEAT BALANCE}

A heat balance performed for each case yielded the following results: for the idling case, $21.6 \mathrm{~kW}$ exit through the electrodes and bottom, with $2.3 \mathrm{~kW}$ through the bottom. For the feeding case, $21.8 \mathrm{~kW}$ exit through the electrodes and bottom, with $2.5 \mathrm{~kW}$ through the bottom. In the prototype LFCM, it is estimated that $20 \mathrm{~kW}$ are lost through the cooling jackets. The simulation results are in good agreement.

\section{TEMPERATURES IN THE REFRACTORY}

Figure 6 shows how the temperatures vary in the refractory surrounding the molten glass for the feeding and idling cases. In both cases, most of the temperature drop in the side walls occurs in the Monofrax K-3. The cooling jackets on the sides enhance cooling there. In the bottom refractory, there is a noticeable difference in the isotherms between the two cases--the bottom 


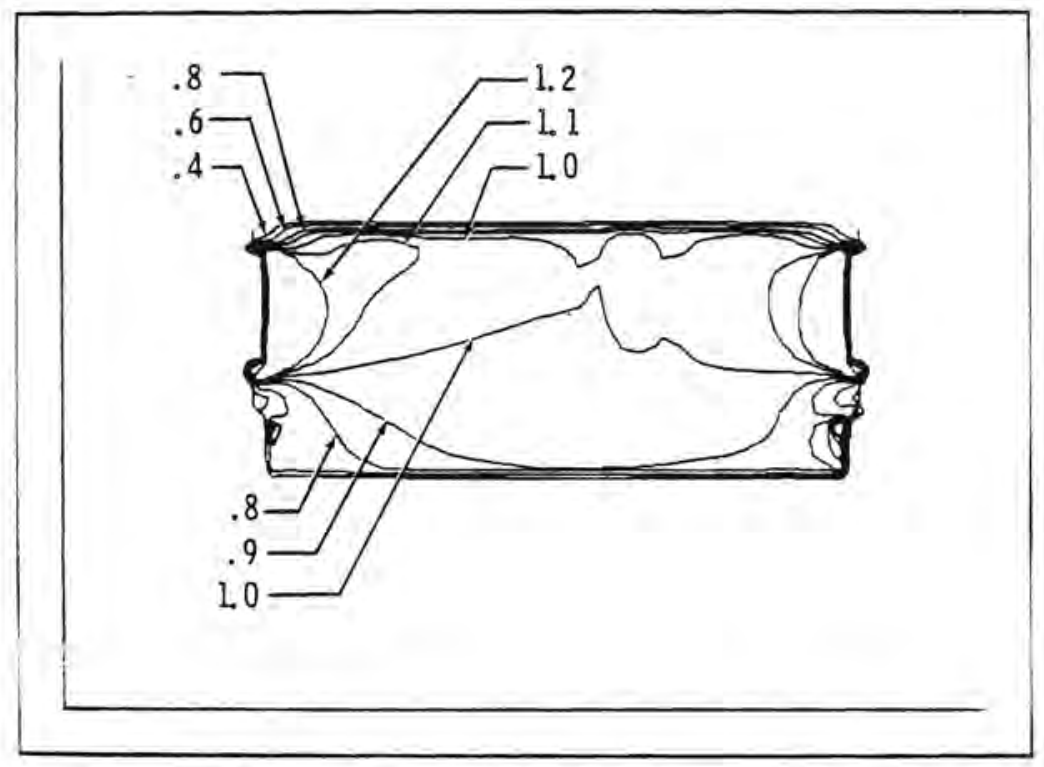

a. During Liquid Feeding

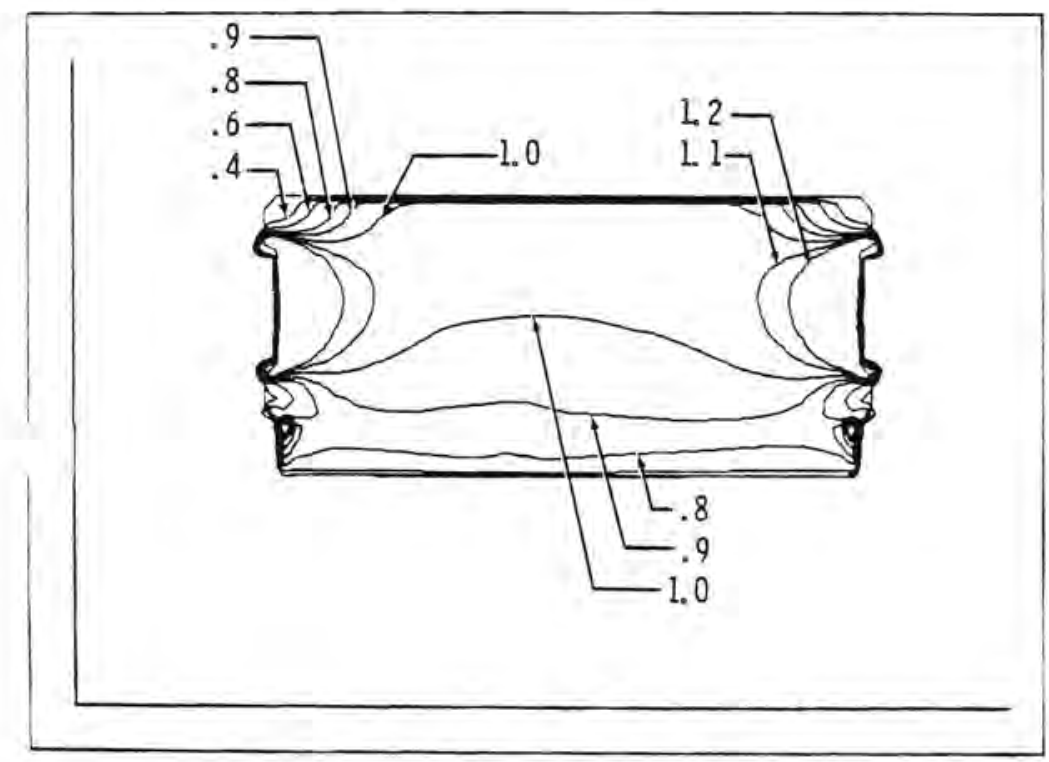

b. While Idling

FIGURE 5. Normalized Heat Generation Rate Contours 


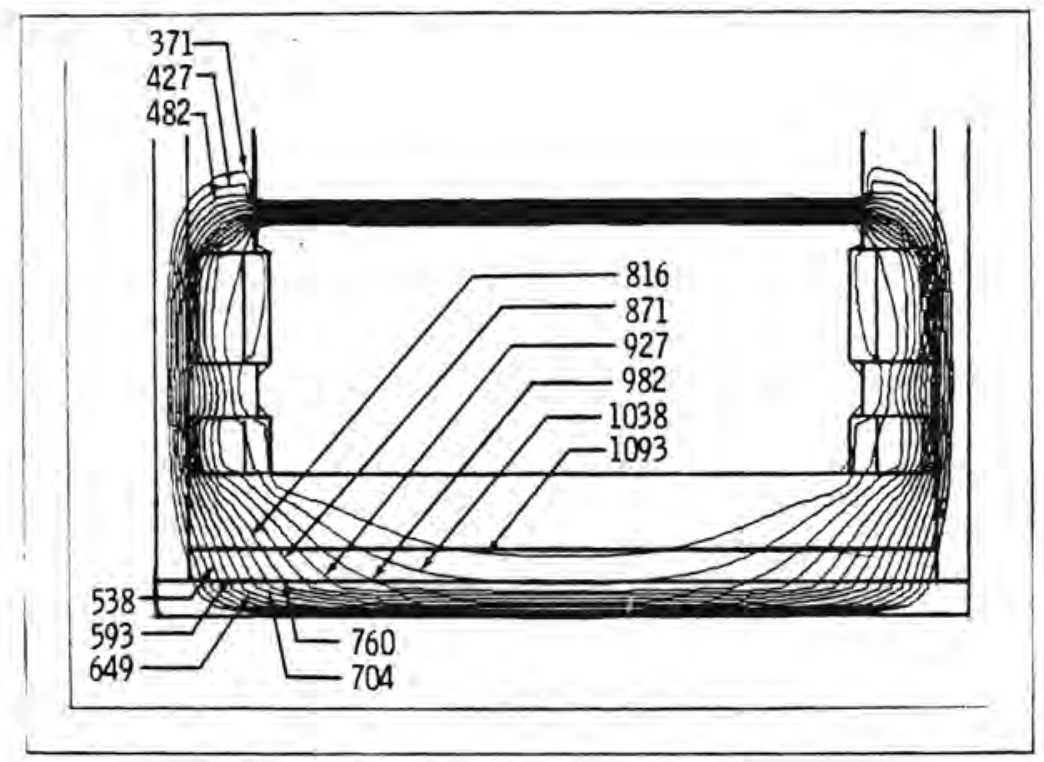

a. During Liquid Feeding

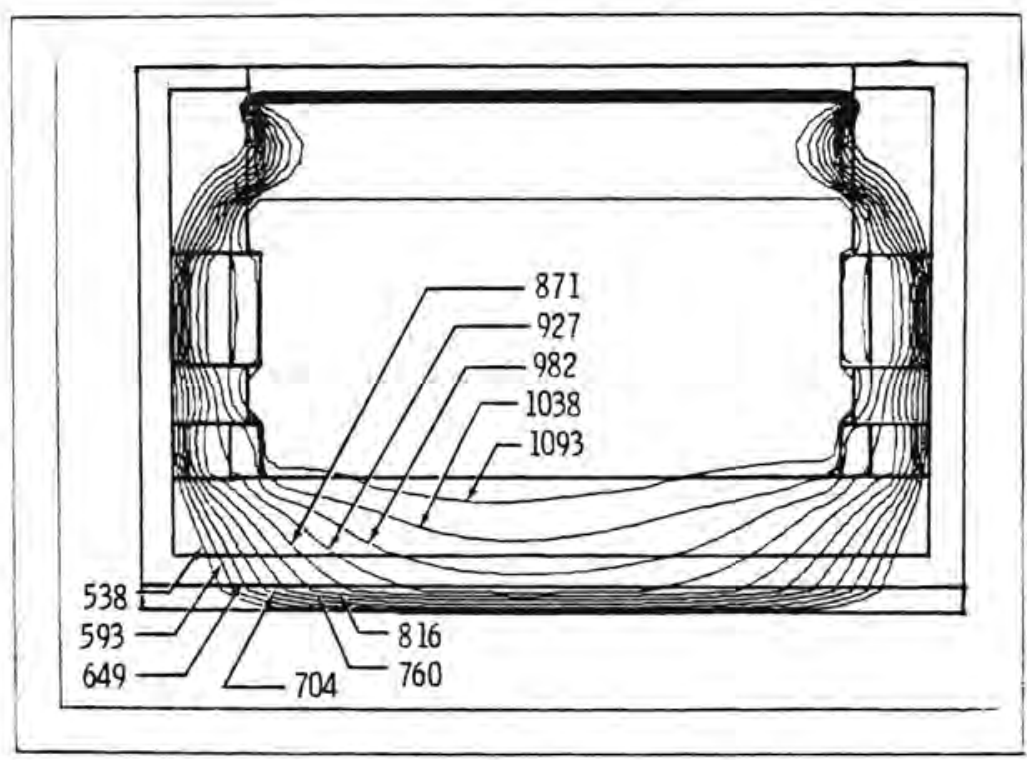

b. While Idling

FIGURE 6. Refractory Isotherms (Contour Values in ${ }^{\circ} \mathrm{C}$ ) 
refractory while feeding is warmer. This is a direct result of the warmer glass temperatures along the central floor region during feeding. Near the batch crust, there is a large temperature gradient in the Monofrax $\mathrm{K}-3$. The peak value of the temperature gradient in the Monofrax $\mathrm{K}-3$ is $573^{\circ} \mathrm{C} / \mathrm{in}$. It occurs immediately below the batch crust, where the glass temperature gradient is steepest. In the idling case, there are no steep vertical temperature gradients, because there is no cold cap above the molten glass.

The temperatures computed in the floor refractory are much warmer than those measured in the actual LFCM. One reason for this result is that the model neglects heat transfer in the direction perpendicular to the plane modeled, i.e., the two-dimensional assumption. Another reason is that the model neglected the freeze valve ${ }^{(1)}$ in the floor, which acts as a heat sink. 


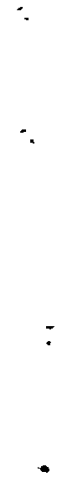

$+$ 


\section{$\underline{\text { DISCUSSION }}$}

The results generated by the numerical simulation of the LFCM in the idling and feeding modes aid in understanding the physical processes of the molten glass. The findings also point out some potential problem areas in LFCM operation.

When switching from idling to feeding modes in the LFCM, the results indicate that the overall glass temperature will increase. This is a good indication that high throughputs are attainable. Another indication of high throughput possibilities is the high glass velocities observed during liquid feeding. High velocities decrease the time required for good mixing, which allows the feed rate to be increased. However, the temperature increase occuring in the feeding mode can result in reboil, $(5,6)$ a sudden release of dissolved gases in the glass, which can turn it into a foam. Reboil can cause complete disruption of the cold cap, thus, precautions must be taken to avoid reboil.

The temperature contours in the refractory during liquid feeding indicate another potential problem area. Near the cold cap, the glass experiences extreme temperature changes in very short distances; large temperature gradients in the adjacent Monofrax $\mathrm{K}-3$ result. The peak gradient, $573^{\circ} \mathrm{C} / \mathrm{in}$., could lead to cracking in the refractory during steady-state, fully flooded operation. Temperature measurements should be taken in the prototype LFCM refractory to verify this result and determine whether or not corrective action is required.

During liquid feeding, the glass temperatures were fairly uniform, with potential cold spots in the bottom corners. With uniform temperatures, there is less chance of phase separation in the glass, i.e., crystals forming and building up along the floor. During idling, the entire LFCM floor area was cold relative to the bulk temperature, indicating a potential phase separation problem. The floor area would be warmer if a larger proportion of the total power were input through the lower electrodes. Skewing the heat generation toward the melter floor increases floor temperature and glass velocities along the floor. (3) Both consequences are desirable. 
The validity of the results rests on the validity of the two major idealizations made in the analysis: 1) that the system is two-dimensional, and 2) that the cold cap can be simplified as was done here. There are obvious shortcomings to neglecting three-dimensional effects. Neglecting heat transfer in one direction results in less power required than in the prototype LFCM to maintain the same temperature. Neglecting wall effects on the fluid flow results in a flow field different from the real LFCM. In simulating the cold cap, the primary goal was to model the heat transfer properly by simplifying a very complex system with several assumptions. The numerical results do not exhibit any major deviations from the prototype LFCM behavior. 


\section{CONCLUSIONS}

The modeling scheme developed to simulate the LFCM during liquid feeding has produced results that showed no major deviations from LFCM behavior. The results indicated positive operating conditions and pointed out some required precautionary measures. Higher fluid velocities and more uniform temperatures occur during liquid feeding, increasing homogeneity and capacity and reducing the possibility of phase separation. However, when switching to the liquid feeding mode from the idling state, glass temperatures will increase and can result in reboil. The results also indicate a high temperature gradient in the Monofrax K-3. A laboratory test should be performed to verify this result. Finally, inputting a larger percentage of power through the lower electrodes will raise temperatures along the floor during idling and help eliminate the possibility of phase separation.

It is concluded that the numerical model can predict trends in the LFCM. Thus, comparisons between the LFCM idling and liquid feeding modes performed in this studv are reasonable. 


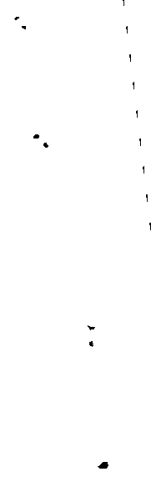




\section{REFERENCES}

1. J. L. Buelt and C. C. Chapman, Liquid Fed Ceramic Melter: A General Description Report. PNL-2735, Pacific Northwest Laboratory, RichTand, WA 99352, October 1978.

2. D. S. Trent, A Numerical Model for Two-Dimensional Hydrodynamics and Energy Transport. BNWL-1803, Pacific Northwest Laboratory, Richland, WA 99352, June 1973.

3. R. L. Hjelm and T. E. Donovan, "A Numerical Investigation of Electric Field Effects on Unsteady Buoyant Molten Glass Flows," ASME Publication 79-HT-98, American Society of Mechanical Engineers, New York, NY 10017, August 1979.

4. M. S. Quigley and D. K. Kreid, Physical Modeling of Joule Heated Ceramic Glass Melters for High Level Waste Immobilization. PNL-2809, Pacific Northwest Laboratory, Richland, WA 99352, March 1979.

5. J. L. Buelt, C. C. Chapman, S. M. Barnes, and R. D. Dierks, "A Review of Continuous Ceramic-Lined Melters and Associated Experience at PNL." PNL-SA-7590, Presented at the International Symposium on Ceramics in Nuclear Waste Management, sponsored by the Nuclear Division of the American Ceramic Society and the U.S. Department of Energy, Cincinnati, Ohio, April 30-May 3, 1979.

6. J. L. Buelt and C. C. Chapman, "Slurry Feeding of Nuclear Waste to an Electric Glass Melter," PNL-SA-7571, Presented at the 50th Annual American Nuclear Society Meeting, Atlanta, Georgia, June 5, 1979. 
$\because$

.

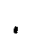




\section{$\underline{\text { DISTRIBUTION }}$}

No. of

Copies

UNITED STATES

A. A. Churm

DOE Chicago Patent Group

9800 South Cass Ave.

Argonne, IL 60439

R. E. Cunn ingham

Deputy Director for Fuels and Materials

Nuclear Regulatory Commission

Silver Springs, MD 20910

T. C. Chee

DOE Office of Nuclear Waste

Management

Washington, DC 20545

C. R. Cooley

DOE Office of Nuclear Waste. Management

Washington, DC 20545

Sheldon Meyers

DOE Office of Nuclear Waste

Management

Washington, DC 20545

R. G. Romatowski

DOE Office of Nuclear Waste Management

Washington, DC 20545

C. A. Heath

DOE Office of Nuclear Waste

Management

Washington, DC 20545

G. Dertel

DOE Office of Nuclear Waste

Management

Washington, DC 20545
No. of

Copies

A. F. Perge

DOE Office of Nuclear Waste

Management

Washington, DC 20545

R. D. Walton

DOE Office of Nuclear Waste

Management

Washington, DC 20545

J. Neff, Program Manager

Department of Energy

Columbus Program Office

$505 \mathrm{King}$ Avenue

Columbus, $\mathrm{OH} 43201$

John Van Cleve

DOE Oak Ridge Operations Office

P.0. Box X

Oak Ridge, TN 37830

E. S. Goldberg

DOE Savannah River Operations Office

P.0. Box A

Aiken, SC 25801

27 DOE Technical Information Center

J. R. Berreth

Allied Chemical Corporation

550 2nd Street

Idaho Falls, ID 83401

Allied Chemical Corporation

(File Copy)

550 2nd Street

Idaho Falls, ID 83401 
A. Williams

All ied-General Nuclear Service P.0. Box 847

Barnwe 11, SC 29812

J. L. Jardine

Argonne National Laboratory

9700 South Cass Avenue

Argonne, IL 60439

M. M. Steindler/L. E. Trevorrow

Argonne National Laboratory

9700 South Cass Avenue

Argonne, IL 60439

Wayne Carbiener

Battelle Memorial Institute

505 King Ave.

Columbus, $\mathrm{OH} 43201$

J. Kircher

Office of Nuclear Waste Isolation

Battelle Memorial Institute

505 King Ave.

Columbus, $\mathrm{OH} 43201$

B. Rawls

Office of Nuclear Waste Isolation

Battelle Memorial Institute

505 King Ave.

Columbus, $\mathrm{OH} 43201$

Brookhaven National Laboratory

Reference Section

Information Division

Upton, NY 11973

J. L. Cranda 11

E. I. duPont DeNemours and Company

Savannah River Laboratory

Aiken, SC 29801

H. L. Hul1

E. I. duPont DeNemours and Company

Savannah River Laboratory

Aiken, SC 29801
R. G. Garvin

E. I. duPont DeNemours and Company Savannah River Laboratory

Aiken, SC 29801

D. L. McIntosh

E. I. duPont DeNemours and Company Savannah River Laboratory

Aiken, SC 29801

J. A. Kelley

E. I. duPont DeNemours and Company Savannah River Laboratory

Aiken, SC 29801

M. D. Boersma

E. I. duPont DeNemours and Company Savannah River Laboratory

Aiken, SC 29801

S. Mirshak

E. I. duPont DeNemours and Company Savannah River Laboratory

Aiken, SC 29801

A. S. Jennings

E. I. duPont DeNemours and Company

Savannah River Laboratory

Aiken, SC 29801

H. Henning

Electric Power Research Institute

3412 Hillview Avenue

P.0. Box 10412

Palo Alto, CA 94301

Environmental Protection Agency

Technology Assessment Division

(AW-559)

Office of Radiation Programs

Washington, DC 20460

R. G. Barnes

General Electric Company

175 Curtner Avenue (M/C 858)

San Jose, CA 95125 
No. of

Copies

Los Alamos Scientific Laboratory (DOE)

P.0. Box 1663

Los Alamos, NM 87544

J. P. Duckworth

Plant Manager

Nuclear Fuel Services, Inc.

P.0. Box 124

West Valley, NY 14171

J. G. Cline, General Manager

NYS Energy Research and

Development Author ity

230 Park Avenue, Rm 2425

New York, NY 10017

Oak Ridge National Laboratory (DOE)

Central Research Library

Document Reference Section

P.0. Box X

Oak Ridge, TN 37830

E. H. Kobisk

Solid State Division

Oak Ridge National Laboratory

Oak Ridge, TN 37830

R. Roy

Pennsylvania Stata University

Materials Research Laboratory

University Park, PA 16802

W. Weart

Sandia Laboratories

Albuquerque, NM 87107

J. 0. Blomeke

Union Carbide Corporation (ORNL)

Chemical Technology Division

P. 0. Box $Y$

Oak Ridge, TN 37830

R. E. Blanco

Union Carbide Corporation (ORNL)

Chemical Technology Division

P. O. Box Y

Oak Ridge, TN 37830
No. of

Copies

D. E. Ferguson

Union Carbide Corporation (ORNL)

Chemical Technology Division

P. 0. Box $Y$

Oak Ridge, TN 37830

H. W. Godbee

Union Carbide Corporation (ORNL)

Chemical Technology Division

P. 0. Box $Y$

Oak Ridge, TN 37830

\section{FOREIGN}

2 International Atomic Energy Agency

Kartner Ring 11

P.0. Box 590

A-1011, Vienna, AUSTRIA

B. Morris

Atomic Energy Research

Establishment,

Harwe 11, Didcot,

Berks, ENGLAND

D. W. Clelland

United Kingdom Atomic Energy

Authority

Risley, ENGLAND

E. R. Merz

Institut fur Chemische

Technologie

Kernforschungsan loge Julich $\mathrm{GmbH}$

D517 Julich

Postfach 365

Federal Republic

WEST GERMANY

R. Bonniaud

Center de Marcoule

B.P. 170

30200 Baguols-sur-Ceze

FRANCE 
No. of

Copiés

C. Sombret

Centre de Marcoule

B.P. 170

30200 Baguols-sur-Ceze

FRANCE

F. Laude

Centre de Marcoule

B.P. 170

30200 Baguols-sur-Ceze

FRANCE

H. Krause

Kernforschungszentrum Kar lsruhe GmbH (KfK)

Postfach 3640

D7500 Kar lsruhe

WEST GERMANY

S. Tashiro

Japan Atomic Energy Research Institute

Environmental Safety Research Laboratory

1-1-13, Shibashi

Minatopku, Tokyo

JAPAN

\section{ONSITE}

3 DOE Richland Operations Office

P. A. Craig

H. E. Ransom

M. J. Zamorski

5 Rockwell Hanford Operations

\author{
L. Brown \\ M. J. Kupfer \\ G. Reep \\ D. D. Wodrich \\ File Copy \\ Exxon Nuclear Company
}

S. J. Beard
No. of

Copies

Westinghouse Hanford Company

A. G. Blasewitz

66

Pacific Northwest Laboratory

S. M. Barnes

W. J. Bjorklund

H. T. Blair

W. F. Bonner

R. A. Brouns

J. L. Buelt

L. A. Chick

A. J. Currie

T. E. Donovan (10)

R. D. Dierks

M. S. Hanson

R. L. Hjelm (10)

L. K. Holton

J. H. Jarrett

D. E. Knowlton

D. K. Kreid

W. L. Kuhn

D. E. Larson

S. A. McCullough

J. L. MCE Troy (3)

G. B. Mellinger

J. E. Mendel

F. A. Miller

R. E. Nightingale

D. E. Olesen

K. H. Oma

C. R. Palmer

A. M. Platt

D. L. Prezbindowski (2)

M. S. Quigley

W. A. Ross

J. M. Rusin

D. H. Siemens

S. C. Slate

A. M. Sutey

C. L. Timmerman

R. T. Treat

D. S. Trent

Technical Information (5)

Publishing Coordination KE(2) 